\title{
Institutionalizing the Internship
}

\author{
Robert Garfrerick \\ University of North Alabama \\ Janna Malone \\ University of North Alabama \\ This paper was presented at the 2018 International Summit of the \\ Music \& Entertainment Industry Educators Association
}

March 22-24, 2018

$\underline{\text { https://doi.org/10.25101/18.29 }}$

\begin{abstract}
"In its simplest form, experiential learning means learning from experience or learning by doing. Experiential education first immerses learners in an experience and then encourages reflection about the experience to develop new skills, new attitudes, or new ways of thinking" (Lewis and Williams 1994). Many MEIEA schools require an internship, indicating the majority of schools place a high value on the concept. However, little is known about how and whether faculty receive course load or other fair compensation for coordinating and facilitating internships.

Both the university and students are beneficiaries of experiential learning. University benefits include recruitment, retention, and job placement. Benefits for the student are motivation, oral and written communication skills, academic performance, and job placement. Recently, the University of North Alabama began including the internship experience in the teaching load of the supervising faculty member, and made a substantial financial commitment by purchasing software specifically used for internship accountability, expectations, and reporting. This has streamlined the means by which the student presents information regarding the internship experience and the way the faculty member receives the information. This paper will address the importance of experiential learning and discuss, through case study information, best practices for facilitating the valuable experience.
\end{abstract}

Keywords: experiential education, field-based learning, internships, co-ops, internship reporting, internship reflection, practicums, music business studies, entertainment industry studies
It was Albert Einstein who once said, "Learning is experience. Everything else is just information." Learning through experience is a widely accepted model, and internships, externships, apprenticeships, and various forms of shadowing have been common for many years. For much of human history the only learning that took place was through experience. In modern history, knowledge gained through experience is treated as a complement to that which is learned in the classroom.

"In its simplest form, experiential learning means learning from experience or learning by doing. Experiential education first immerses learners in an experience and then encourages reflection about the experience to develop new skills, new attitudes, or new ways of thinking" (Lewis and Williams 1994). The general concept of learning through experience has been around for thousands of years. Around 350 B.C., Aristotle wrote in the Nichomachean Ethics, "For the things we have to learn before we can do them, we learn by doing them" (Aristotle n.d.). Early theories of experiential learning were attempts by teachers to take a different approach to traditional formal education. Teachers challenged the students to "learn by doing," applying experiential knowledge to develop skills or new ways of thinking (Lewis and Williams 1994).

"Simple participation in a prescribed set of learning experiences does not make something experiential. The experiential methodology is not linear, cyclical, or even patterned. It is a series of working principles, all of which are equally important or must be present to varying degrees at some time during experiential learning. These principles are required no matter what activity the student is engaged in or where the learning takes place" (Chapman, McPhee, and Proudman 1995). Experiential education is different from didactic education where the role of the instructor is to provide or teach information. It is to prescribe and structure learning experiences. It is in creating and structuring these appropriate experiences where true experiential learning takes on meaning. 
It is generally accepted that there are two types of experiential learning: learning by oneself through participation in events, known as informal learning, and experiential education through participation in activities structured by others. It is this second type that represents most experiential learning through internships and co-ops. Lewis and Williams (1994) further identify experiential learning into two categories. The first is classroom-based learning such as role-playing, case studies, and group work. Secondly, there is field-based learning with internships, service learning, and practicums. Experiential learning includes learning that comes about through reflection of everyday experiences. The role of the experiential educator is to organize and facilitate direct experiences under the assumption that it will lead to meaningful and long-lasting learning (Neill 2006).

The key to successful experiential learning is structuring and implementing activities external to the classroom. With field-based learning and internships, learning tends to be informal. "Making something of this chaotic learning situation is confusing for a learner who is used to being 'fed' information in lectures" (Moon 2004). It is further suggested that structured learning outcomes, reflection, briefing sessions, and assessment criteria can help learners process the experience (Moon 2004).

Reflection is critical to experiential learning and most internships require this in the form of journaling or other similar reports back to the supervising faculty member. Reflection does not come naturally to many students. Moon advocates a two-stage process for reflection. The first is Presenting Reflection in which the student receives some instruction on how to reflect. This can be accomplished through a variety of methods, such as giving examples, offering a starting exercise, showing how reflective writing is different from other forms of writing, and providing opportunities for reflection in class. The second stage is Facilitating Deeper Refection, which involves stepping back from oneself, using different viewpoints to the same issue, deepening reflection by collaboration with others, and using exercises that promote reflection influenced by emotion reaction (Moon 2004).

Many Music and Entertainment Industry Educators Association (MEIEA) schools require an internship or other experience, indicating the majority of schools place a high value on the concept. In fact, currently over $75 \%$ of the fifty-nine member schools require the internship (MEIEA n.d.). A 2016 study by Garfrerick indicates the internship as a required course ranked second among forty-seven MEIEA schools - second to only the required broad-based introductory survey class (Garfrerick 2016). Of the remainder schools, who do not require an internship experience, most offer it as an elective course or experience. Anecdotal reports from faculty members at institutions which do not re- quire the internship indicate that students overwhelmingly take advantage of the elective experience. Students and faculty traditionally view the internship as a launch point for the career. The internship allows the student the opportunity to put the concepts, theory, and methods they learned in the classroom into practice through direct involvement with supervisory personnel in a professional work environment.

As much as the concept of experiential learning is highly valued among MEIEA schools, little is known about how and whether faculty members receive course load or other fair compensation or additional resources for coordinating and facilitating internships. Anecdotal information indicates that there are multiple models for institutionalizing the internship. Some schools grant load credit to the supervising faculty member, or export that function from the department to the Career Services office. Others expect the faculty member to take those on as an overload, yet others expect the instructor to supervise interns in what appears to be part of the faculty member's service portfolio.

In the academic year 2016-2017 through its Emerging Leaders program, the University of North Alabama (UNA) College of Arts and Sciences tasked a faculty member with investigating experiential learning. The project had three primary goals: The development of sustainable workload models for faculty direction of experiential learning opportunities, the promotion of high quality experiential learning opportunities by sharing best practices, and the provision of recommendations for the systematic documentation of experiential learning opportunities. Eleven faculty from eight disciplines and departments participated in a pilot study where they were given in-load credit or $\$ 1,800$ overload pay for supervising experiential learning activities. These included study abroad trips, internships, and fieldwork/capstone projects. As a result, several faculty members across those disciplines now regularly receive in-load credit for supervising internships. Some were unable to make the transition due to short staffing in those departments.

Until recently, the internship coordinator in the Department of Entertainment Industry at UNA was compensated $\$ 120$ per student ( $\$ 40$ per credit hour), up to $\$ 1,800$, as overload pay for overseeing student interns. Data collected in the department over the last decade shows an average of 38 students per year registering for the internship or 12.67 students each fall, spring, or summer. With consistent numbers in this range, the university decided the faculty member coordinating the internships should receive course load credit for overseeing the internship experience. The pilot program afforded an opportunity to illustrate what improvements can be made to those experiences if the faculty member has adequate time to coordinate and supervise them.

Another positive outcome of the project relates to the systematic documentation of the experience. The universi- 
ty made a substantial financial commitment by purchasing software specifically used for internship accountability, expectations, and reporting. This has streamlined the means by which the student presents information regarding the internship experience and the way the internship coordinator receives the information. The software allows immediate access by the internship coordinator to all internship information entered into the system by the student intern. Prior to using the software, students submitted internship journals at midterm and then again at the end of the semester. The new software allows the internship coordinator to troubleshoot any problems reported in the journal by the student and also provides the ability to intercede if information is inadequate. This enables the internship coordinator to intervene and immediately assist the student if necessary, keeping the student on track to satisfactorily complete the internship requirements.

Melissa Medlin, Director of Career Services at UNA, states, "Numerous software were researched, and it was determined Symplicity was the strongest experiential learning module to track students and encapsulate data" (Medlin 2018). Symplicity is a comprehensive solution for posting co-op and internship positions, managing applicants, processing evaluations, and tracking offers ("CSM: Career Services Manager" n.d.). The university pays an annual licensing fee for use of the software.

In the Fall 2017 semester, the internship coordinator in the Department of Entertainment Industry at UNA participated in the pilot program along with two other internship coordinators in two separate departments. The pilot program was successful, and other departments offering experiential learning opportunities now use Symplicity for student reporting.

Symplicity prepares students for the job hunt, boosts the institution's return on investment with post-graduation data, increases hiring outcomes, and builds key relationships with employers ("CSM: Career Services Manager" n.d.). Before beginning the internship, students must submit internship information into Symplicity. Students are given instructions on how to enter experiential learning and internship placement data into the system. This information includes name, course number, course section, credit hour, work term, job title, start date, end date, email, phone number, work department, compensation, hours per week, supervisor name, supervisor department, supervisor title, supervisor phone number, supervisor email, how the internship was found, and a brief job description. The student must also list three learning objectives to be fulfilled during the internship experience. The student states tasks and strategies for fulfilling the objectives, and an evaluation of each objective is completed by the student. These objectives and activities will vary from student to student and are individualized to meet the needs of the student and the internship placement.

Once the student submits the experiential learning information into the system, Symplicity will generate an evaluation form that is emailed to the internship supervisor. After the student has fulfilled the internship hourly requirement, the internship supervisor completes the evaluation based on the internship performance of the student. All information submitted by both the student and the internship supervisor are kept in one place that streamlines the reporting process. This also enables faculty to easily retrieve the information for future use and creates an internship placement database for students to peruse when looking for experiential learning opportunities.

The Department of Entertainment Industry at UNA has evolved from a program in a music unit, to an interdisciplinary program, and finally to a stand-alone department. Over the course of this forty-three-year history, the faculty has debated whether to keep the internship as a requirement or offer it as an elective in the major. The faculty continues to see the benefits of the internship to the student and has opted to keep it as a degree requirement. This is largely due to witnessing students who are average performers in the classroom thrive and excel when putting to practice what was learned in the classroom. Over the years, faculty members have observed students who were reluctant to step out of a comfort zone complete the internship and ultimately land their dream jobs. Continually, the internship coordinator receives evaluations with excellent marks for students who have received average grades in the classroom.

Both the university and students are beneficiaries of experiential learning. Universities that promote experiential learning report increases in student recruitment (Martin 1997), retention (Nagada et al. 1998), graduation rates (Plotkowski and Joseph 2011), and job placement (Chi and Gursoy 2009). Students who participate in experiential learning report significant increases in motivation and focus on the major (Lowenthal and Sosland 2007), oral and written communication skills (Feldman, et al. 2006), academic performance (Bauer and Bennett 2003), graduate school admission (Hathaway, Nagada, and Gregerman 2002), and job placement. Ninety-five percent of employers report that a major factor in the hiring decision process is experience outside of the classroom (Chi and Gursoy 2009).

It is evident that educators need to prepare students for a career in the workforce. There are three fundamental "E's" that students should remember when entering the working population: engage, equip, and empower. Experiential learning offers students much more than a "textbook" education. Experiential learning provides sensory participation - an immersive experience that aligns aspirations to a purpose or direction. It builds character and gives them a sense of ownership for their futures (Potter 2017). 


\section{Bibliography}

Aristotle. Nicomachean Ethics. Translated by W.D. Ross, n.d. Accessed January 2018. http://classics.mit.edu/ Aristotle/nicomachaen.2.ii.html.

Bauer, Karen W., and Joan S. Bennett. "Alumni Perceptions Used to Access Undergraduate Research Experience." Journal of Higher Education 74, no. 2 (2003): 210-230. https://doi.org/10.1080/00221546.2003.1177 $\underline{7197 .}$.

Chapman, Steve, Pam McPhee, and Bill Proudman. What is Experiential Education? Dubuque, Iowa: Kendall/ Hunt Publishing Company, 1995.

Chi, Christina, and Dogan Gursoy. "How to Help Your Graduates Secure Better Jobs? An Industry Perspective." International Journal of Contemporary Hospitality Management 21, no. 3 (2009): 308-322. https:// doi.org/10.1108/09596110910948314.

"CSM: Career Services Manager." Symplicity. Accessed January 18, 2018. https://www.symplicity.com/higher-ed/solutions/csm.

Feldman, Ann M., Tom Moss, Diane Chin, Megan Marie, Candice Rai, and Rebecca Graham. "The Impact of Partnership-Centered, Community-Based Learning on First-year Students' Academic Research Papers." Michigan Journal of Community Service Learning 13, no. 1 (2006): 16-29.

Garfrerick, Robert. "Does a MEIEA Core Curriculum Exist? A Survey of Practice." Paper Presented at the International Summit of the Music and Entertainment Industry Educators Association, Washington, D.C., 2016.

Hathaway, Russel S., Biren A. Nagada, and Sandra R. Gregerman. "The Relationship of Undergraduate Research Participation to Graduate and Professional Education Pursuit: An Empirical Study." Journal of College Student Development 43, no. 5 (2002): 614-631.

Jackson, Lewis, and Rosemary S. Caffarella. Experiential Learning: A New Approach. San Francisco: JosseyBass, 1994.

Lowenthal, Diane J., and Jeffrey K. Sosland. "Making the Grade: How a Semester in Washington May Influence Future Academic Performance." Journal of Political Science Education 3, no. 2 (2007): 143-160. https:// doi.org/10.1080/15512160701338312.

Martin, Gary R. "A Case Study of Student Recruitment and Education Implications for Colleges Considering Mandatory Co-op." Journal of Cooperative Education 32, no. 3 (1997): 96-101.

Medlin, Melissa. Interview by Janna Malone, February 1, 2018.
Moon, Jennifer A. A Handbook of Reflective and Experiential Learning: Theory and Practice. New York: RoutledgeFalmer, 2004.

"Music and Entertainment Industry Educators Association. " MEIEA.org. Accessed January 15, 2018. http:// meiea.org.

Nagada, Biren A., Sandra R. Gregerman, John Jonides, William von Hippel, and Jennifer S. Lerner. "Undergraduate Student-Faculty Research Partnerships Affect Student Retention." The Review of Higher Education 22, no. 1 (1998): 55-72.

Neill, James. "Experiential Learning \& Experiential Education: Philosophy, Theory, Practice, \& Resources" last modified May 10, 2006. Accessed January 18, 2018. http://wilderdom.com/experiential/.

Plotkowski, Paul D., and Jann Joseph. "Enhancing Graduation Rates through High Impact Activities: Experiential Learning, Engagement, Mentoring, and Scholarships." Proceedings of the American Society for Engineering Education Annual Conference 1-9, 2011. http://www.asee.org/public/conferences/1/papers/122/ view.

Potter, Andrew. "How Experiential Learning Helps Students Own Their Future." Education Dive, June 20, 2017. Accessed February 22, 2018. https://www. educationdive.com/news/how-experiential-learning-helps-students-own-their-future/445198/. 


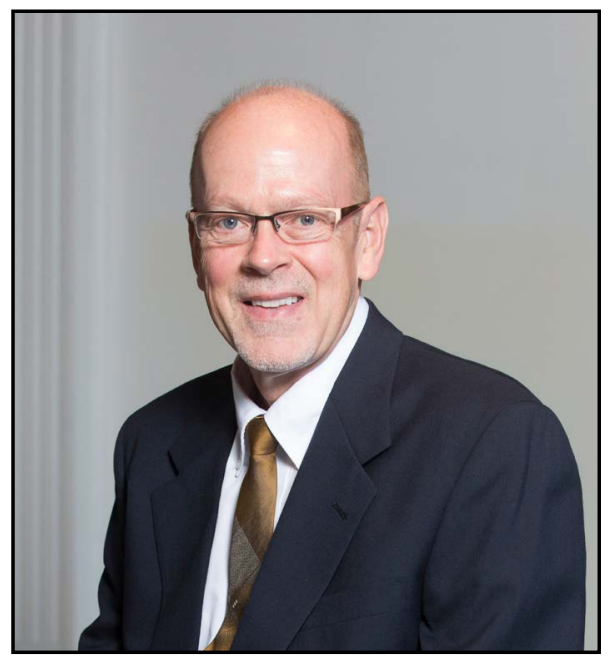

Robert Garfrerick is Professor and Eminent Scholar in Entertainment Industry at the University of North Alabama. Dr. Garfrerick teaches music business and songwriting classes. In addition to his teaching duties he is the Chair of the Department of Entertainment Industry. He has written songs recorded by Crystal Gayle, T. G. Sheppard, Marie Osmond, Johnny Lee, Gus Hardin, David Slater, and others. Dr. Garfrerick has a bachelor of music degree from the University of Alabama, a Master of Arts in music from Middle Tennessee State University, and a doctorate in education from Tennessee State University. His research interest is in the areas of creativity, songwriting, and curriculum development. He presents and publishes this research regularly. Additionally, Dr. Garfrerick has been a speaker, presenter, performer, or clinician for groups such as The Songwriter's Guild of America (SGA), The Balsam Mountain Songwriter's Camp, Nashville Songwriters Association International (NSAI), and the Music and Entertainment Industry Educators Association (MEIEA). He is a voting member of the National Academy of Recording Arts \& Sciences (NARAS); a member of The American Society of Composers, Authors, and Publishers (ASCAP), the Muscle Shoals Music Association (MSMA), The Blues Foundation, and MEIEA.

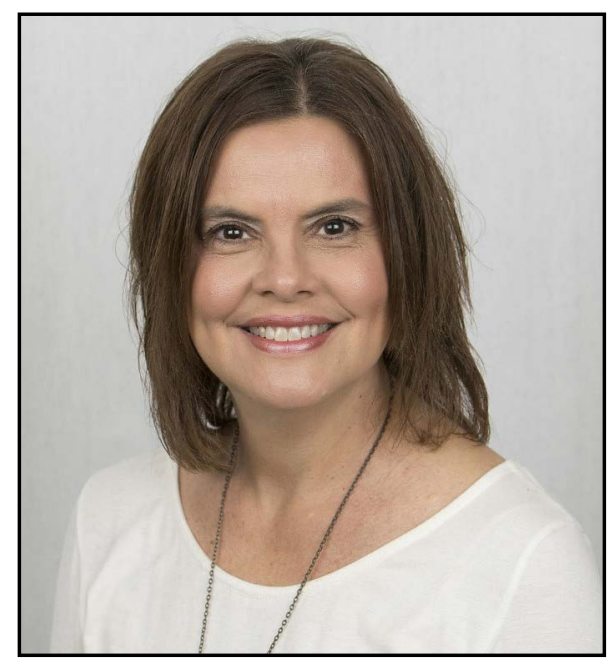

Janna Malone is an Instructor in the Department of Entertainment Industry at the University of North Alabama. Ms. Malone holds a Bachelor of Science Degree in Commercial Music and a Masters in Business Administration from the University of North Alabama. She teaches music business classes and coordinates internships. Prior to her work at UNA, Ms. Malone was employed at FAME Recording Studios in Muscle Shoals, where she served as Executive Administrator of the publishing and production companies. She is a Muscle Shoals Music Association board member and a member of the Music and Entertainment Industry Educators Association. 


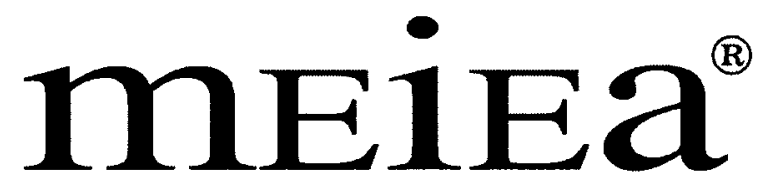

MUSIC \& ENTERTAINMENT INDUSTRY

EDUCATORS ASSOCIATION

\section{PROCEEDINGS OF THE \\ 2018 INTERNATIONAL SUMMIT}

OF THE

\section{MUSIC \& ENTERTAINMENT INDUSTRY EDUCATORS \\ ASSOCIATION}
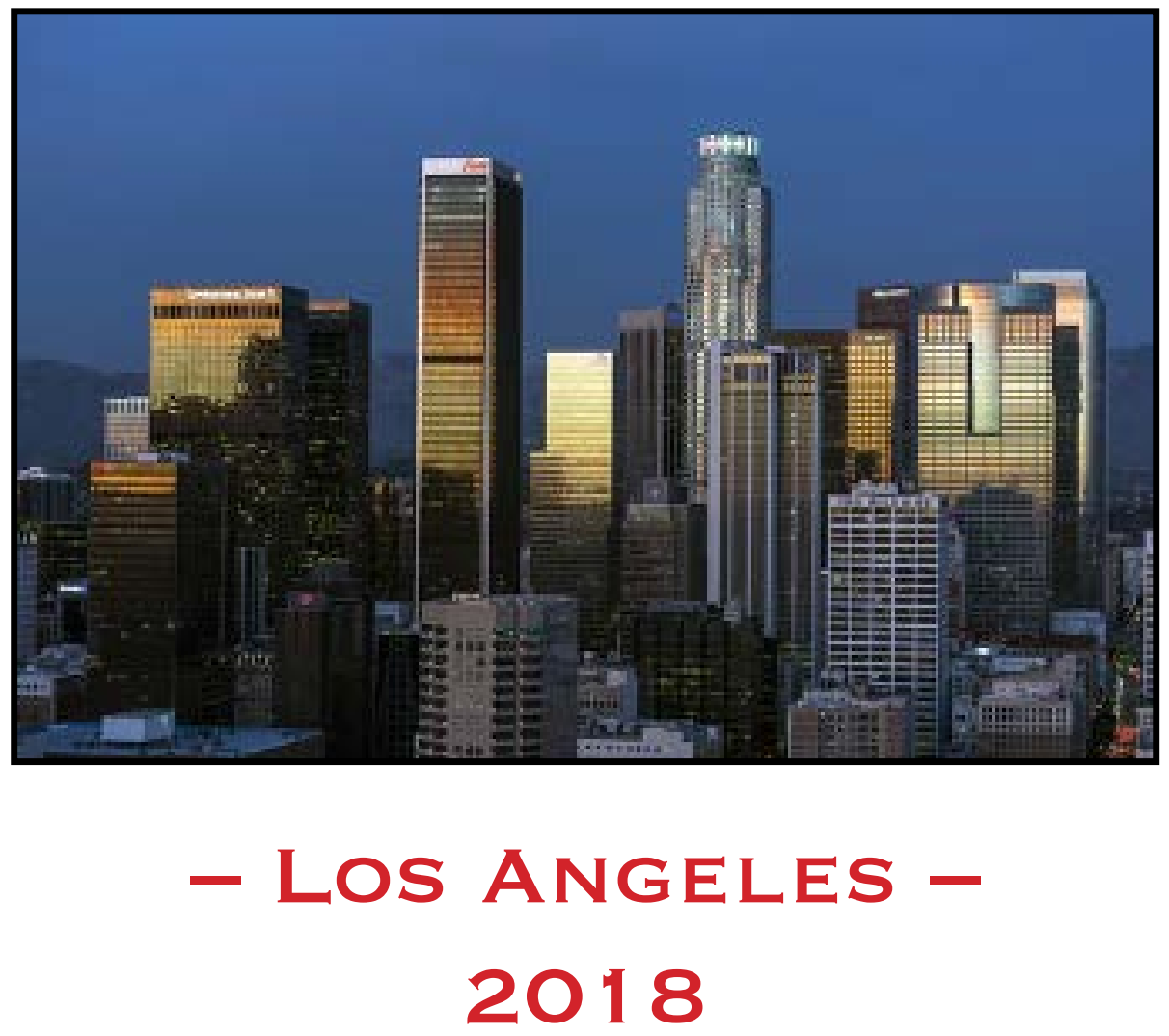

March 22 - 24, $2018 \cdot$ Embassy Suites by Hilton - Los Angeles/Glendale 